verging in the east," but the point is apparently below the visible horizon. Shortly after I had, however, the opportunity of seeing the true convergence, as we were crossing the Peasemarsh, a large common near here. It was after rain, and there appeared a very bright spot in the east opposite the true sun, which to the best of my recollection was setting and not set, for I momentarily took the appearance to be some form of reflection of the sun itself. The rays were quite strong in the east and west, and though fainter could be distinctly traced across the sky. I believe that there were no clouds and that the ray intervals were equidistant, though I will not be certain on this point. I notice that one of my drawings also shows this peculi irity, though I confesss my impression has been hitherto that these rays were due to the interference of clouds.

Guildown, Guildford, Nov. 24

\section{On the Isomerism of Albuminous Bodies}

AMONG organis compounds there are large number of bodies hoving the same composition, but different constitution. They are called isomerides. The number of these isomerides increase in proportion as the number of atoms which they contain increases.

Prof. Cayley has already calculated the possible number of isomerides of hydrocarbons. From his result it can be easily seen that the increase of isomerides in proportion to the complexity of the composition is an exceedingly rapid one.

Now the number of atoms which the so-called albuminous bodies contain are very large. The number of isomerides which they can give therefore must be exceedingly large, in fact almost innumerable.

Prof. Schorlemmer, in his "Rise and Development of Organic Chemistry," says : "The enigma of life can only be solved by the synthesis of albuminous compounds." If then these albu minous bodies are really the basis of life, the different species of living beiags must come from innumerable sources, for albuminous bodies have innumerable isomerides. According to this theory, we can say that the different species of living beings, whether animals or plants, were developed out of the chemical compounds having the same composition, but different constitution, but cannot assert, as some do, that they were developed out of the same source, or a few sources

Tokio, Japan, October I 2

SHigetaké SAgIURA

\section{An Extraordinary Lunar Halo}

ON Monday evening, November 20, an unusual balo surrounded the moon from 6.15 to 6.25 . The moon was not quite full, and the halo to some extent assumed the form of the moon. The halo consisted of a succession of concentric rings. The ring next the moon was equal to four diameters of the moon, and had a soft yellow-white radiance, almost equalling the moon in brilliancy ; it was surrounded by a succession of prismatıc rings, red commencement, and proceeding outward orange, yellow, green, blue, indigo, and violet. At 6.15 the chromatic rings were pretty sharply defined, with the exception of the outer one, which was faint and evanescent. Outside of the ring was a corona-like envelope. This aspect continued about five minutes, and during the next five minutes rapidly changed; the edges of the rings became irregular, radii shot from the rings towards the moon, and at 6.25 the phenomenon disappeared.

Newcastle-on-Tyne, November 24

J. P. BARKas

\section{Meteor}

A BRIGHT meteor was seen here about 4.30 p.m. in the east. It did not explode, but dissipated itself with scintillations. It reached a very low level before it disappeared.

Oxford, November 27

W. L. HARNETT

\section{Flame in Coal Fire}

The flame referred to by Major Herschel (NATURE, vol. xxvii. p. 78) is simply that of carbon monoxide, which may be observed in most coal fires, after the hydrocarbons are connsumed, burning with a pale blue flame. Any yellow tint is of course due to sodium present in the coal. The production of carbon monoxide depends more upon the arrangement of, than the quality of, the coal. Major Herschel will find the reason of its presence give in any text-book on chemistry.
I cannot understand what advantage is obtained by removing the slit of the spectroscope, especially if one wishes to show that a flame is mono-chromatic. When burnt at ordinary pressure, carbon-monoxide has no definite spectrum.

SM.

Rugby, November 24

\section{Waterspouts on Land}

I AM of opinion that the phenomena referred to by Mr. Hossack are not the effect of waterspouts, but are rather to be attributed to landslips. I may mention a case which may throw some light on the matter. About 1872 (I cannot give the exact date) a landslip occurred on the banks of the Tay, about seven miles north of Dunkeld, close to Guay Station on the Highland Railway, and on the east side of that line. I lived close by at the time, and shortly afterwards saw the effects. Local opinion attributed it to the following causes:-Along the top of the gravelly slope planted with oak and other trees, ran a brook. Immediately above the place where the landslip occurred, the banks of the brook had been burrowed by rabbits. When the sudden flood occurred which caused the landslip, the water of the brook entered these holes, undermined the gravelly slope or teriaced beach, and precipitated it across the highway into the field below, devastating fully an acre of it. 'The trees, turf, \&c, were deposited in the field much as they grew upon the slope. I was surprised that they had not been overturned, but it would appear that they had slid down. The effects are stil quite visible to passengers on the railway. Had they been photographed at the time, they would have formed a capital illustration for a geological text-book.

Guildhall Offices, Carlisle

JOHN GedDES MCINTOSH

\section{NOTES FROM THE LETTERS OF CAPTAIN DAWSON, R.A., IN COMMAND OF THE BRITISH CIRCUMPOLAR EXPEDITION}

MAY 21. On board the s.s. "Nova Scotian."-A grey sky MI a grey foam-flecked sea, floating ice-floes, fog and rain, with a thermometer a few degrees above freezing such are the features of the Gulf of St. Lawrence this morning, and a cheerful welcome to the New World. Our course has been a long way to the south of Newfoundland on account of the ice, consequently our passage has been a long one. Yesterday was quite lovely, several icebergs were in sight eight or ten miles off, looking like peaks of snow mountains at a distance; now we are in the midst of ice fields delaying us a good deal, as at times it is difficult to find a passage.

May 22. Quebec.-We sighted land last night, and saw such a lovely sunset as we went up the St. Lawrence. We have been steaming up the river eighteen hours, but we cannot yet see the land on both sides. We have just passed the Peruvian, which left Liverpool a fortnight before us, but she got among the ice and broke her screw, and has been twenty-seven days on the voyage. Another of the Allan line steamers ran into an iceberg. So we feel lucky in getting across without mishap. At the end of the week I start for Winnipeg-2,500 miles by rail-a long journey of five days and four nights.

I find Quebec quite wintry after England; indeed, the snow is still lying in sheltered places where it has drifted, and no trees are in leaf.

Fune 3. On Lake Huron.--On reaching Toronto we went back again into summer-everythirg was green and spring-like, and the air was quite soft and balmy.

We left Toronto for Sarnia, where we embarked for Duluth, on the west end of Lake Superior-thence it is about twenty-four hours' journey to Winnipeg. Toronto was looking very well. There are groves of horse-chestnut trees in the principal streets, which have a very good effect. At Toronto I was introduced to the Canadian Premier, who took a great interest in my expedition. I also dined with the chief of the observatory there, and they gave me some wine at dinner which was made from their own vines in the suburbs. To Sarnia is about six hours-a most fertile country. The weather, however, is very rainy at present - this is the wet time of the year. 